\title{
INVESTIGATING STUDENTS' MONITORING STRATEGIES IN LISTENING COMPREHENSION III OF ENGLISH DEPARTMENT AT STAIN BATUSANGKAR
}

\author{
Elfi \\ Program Studi Pendidikan Bahasa Inggris Jurusan Tarbiyah STAIN Batusangkar \\ Korespondensi: Perumahan Permata Rizano Blok S, Cubadak, Kec. Limakaum Batusangkar \\ e-mail: elfiemulyadi@gmail.com
}

\begin{abstract}
One of the strategies of metacognitive introduced by the listening lecturers in listening comprehension III at STAIN Batusangkar is monitoring strategies. It is assumed that these strategies can help students solve their problem in listening comprehension in order to comprehend oral text correctly. The purposes of this research are to investigate what kind of students' monitoring strategies are used and how they applied it in listening comprehension.The research method was descriptive qualitative.The participants of the research were English students who took listening comprehension III. 91 students were involved as the respondents to answer the questionnaire, and 12 students among them were selected to be interviewed using snowball sampling technique. The data of the research were collected by using questionnaire, interview, and observation. After analizing the data, it was found that most of students used monitoring strategies. These strategies include as: ask if it makes sense, selected attend, deduction, personalizing or contextualizing, taking note, using imagery, self talk, and cooperative strategy. They had applied these strategies in many ways but some of the them did not do it properly. Based on these findings, It can be concluded thatmonitoring strategies used by the students in listening comprehension need to enhance into the correct ways to get better comprehension in listening.
\end{abstract}

Key words: Investigating, Metacognitive strategies, Monitoring strategies, Listening Comprehension.

\section{INTRODUCTION}

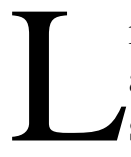

isteningis the ability to identify and understand what others are saying. This involves understanding a speakers' accent or pronunciation, his grammar, his vocabulary, and grasping his meaning. Especially for English Foreign Language (IFL) students, an ability to listen English oral text should be possessed because listening has rightly assumed a central role in language learning.
Listening comprehension is needed by the students. By comprehending the text, they can complete listening task well, but it is not easy way for the students. Some of them feel most frustrated and helpless. One of strategies that can solve their problem in completing listening task is metacognitive strategies. Many research finding reported that metacognitive strategies play an important role in listening. It helps students to improve 
their listening comprehension since this strategies guide the students to plan, to monitor, to solve and to evaluate their listening process. Oxford (1990: 136) conceptualizes metacognitive strategies as" actions which go beyond purely cognitive devices, and which provide a way for learners to coordinate their own learning process". He suggests the students to use them in listening comprehension since it contribute to guide the students to govern their listening process in order to improve their listening comprehension.

Prominent scholars (Chamot (1999), Oxford (1990), and Papaleountioue (2008) are suggested four strategies in metacognitive, they are: planning, monitoring, problem solving and evaluating strategies. In this article, the researcher focuses on discussing monitoring strategies since the problem of the research is closely related to these strategies. There were many problems of monitoring strategies found in the second year students in listening comprehension of English Department at STAIN Batusangkar. The researcher did preliminary observation in listening comprehension class. She observed and interviewed many students. Based on the observation and interview was found some of the students had problems in applying monitoring strategies in whilst listening activities. While they were listening, they were seldom to check their comprehension by asking whether the text made sense for them. It affected to the way they identified the problem in listening activities. They also got trouble to identify specific information of the text, as a result they could not identify critical information and lost their understanding of the text that affected to their comprehension. In addition, they did not know how to use the language rule such as grammar, phonology and morphology in comprehending the text. In spite of this, by understanding and using language rule in listening they could comprehend what the speaker said easily and they could produce the language accurately. Furthermore, they got trouble in contextualizing the information from the text recorded in their mind. While they were listening, they should contextualize the text with their background knowledge and experience. If they did not do it, they would have problem to memorize and to make the information meaningful. The next problem is taking a note. They did not have effective way in taking a note; as a result they missed important information from the text that affected to their comprehension. Less imagination while listening the text also the problems were faced by students. Most of them seldom used their imagery in order to help them remembering what information they listened. If they used their imagery, they could form the picture in their mind in order to make sense and understand the text. Besides, they could not manipulate the object, role playing and pantomiming the situation that related with the topic in order to understand the text easily. Less of self talk while they were listening the text also the problem was found in the classroom. Most of the students seldom to talk with themselves while they were listening the text. They could not make positive statement in their mind so that they lost their confidence in comprehending the text. Finally, in completing the task, they did not cooperate with their friend or lecturer. If they did not know how to answer the questions in the task, they just kept silent and did not complete the task well. It could be seen when they did the task which was given by the lecturer. 
Based on the problem above, the researcher conducted a research about monitoring strategies that were used by students and the way they applied in Listening Comprehension III of English Department at STAIN Batusangkar.

\section{METACOGNITIVE STRATEGIES IN LISTENING COMPREHENSION}

Metacognitive strategies is one of strategies is used in listening comprehension. These strategies can help the student to comprehend the text. O'Malley, Chamot and Kupper (1998) and Rubin (1994) suggest that metacognitive strategies involve knowing about learning and controlling learning through planning, monitoring and evaluating the learning activity. Goh (2006:92)explain that metacognitive strategies refer to 'an understanding of the ways different factors act and interact to affect the course and outcome of cognitive enterprises". In particular, O'Malley, Chamot, and Kupper (1998) and Goh (1998) describetwo strategies in monitoring processes whilst listening activities namely; selective attention and directed attention. Selective attention refers to focuss on specific information as directed when beginning to listen, while directed attention focuses on a general sense of the task demands and content. Meanwhile, Vandergrift (2004) points out four metacognitive strategies namely prediction, monitoring, problem solving and evaluation. More ever, Wenden(1987:25) states, "metacognitive strategis are used to oversee, regulate or self-direct language learning". $\mathrm{He}$ focused on what learners know about various aspects of their language learning and how this influences their choice of strategies. Furthermore, he identified several planning strategies which is used by the students. Students may choose what they want to learn and how they should learn a language. By choosing and prioritizing, they can set their own learning goal. Finally, students may plan what their learning strategies should be and change them if they are not successful.In addition, O'Malley in wenden and Rubin (1987:25) states, "an extended list of planning strategies: "self management, advance preparation, advance organizers, direction attention, selective attention and delayed production".

From the previous theories above it can be conclude that metacognitive strategies may include planning, monitoring, problem solving and evaluating strategies. In planning strategies, the learners may activate their background knowledge about the incoming input, and set a purpose and propose some questions before listening. Monitoring deals with maintaining an awareness of what has previously been set up and tracking information if it satisfies the questions and tasks. Problem solving refers to identifying a particular problem that may occur while listening and finding the solution to the problem. Evaluation allows the learners to reflect upon their involvement during the process of listening by identifying the strengths and weaknesses. Such strategies would obviously be applied throughout the pedagogical sequence of pre-listening, listening and post-listening activities so that such a sequence attains meaning.

\section{MONITORING STRATEGIES IN LISTENING COMPREHENSION}

It is no doubt that students' self monitoring is needed to monitorthe learning in listeningdue to it can encourage them to write down their most significant difficulties in their listening and try to eliminate them. It is also used to track the cause of the problem in listening. They can evaluate their listening comprehension by using 
checklist, diaries, or journals. It can help them evaluate their progress. The more specific the students in self monitoring, the more accurate the comprehension is.

Chamot (1999) suggests nine strategies in monitoring that can be applied by the students in listening comprehension. The first strategy isasked if it makes sense.This strategy encourages checking students understanding of listening text by asking themselves whether the text is making sense to them. By using this strategy, the students can keep track of what they are doing to identify the problems. The second strategy is selectively attend. This strategy motivates choosing to focus on specific aspect of language or situational details that will help the students to perform the task. To apply this strategy the students decide to focus on specific information in the listening text to make them easier to identify the critical information to get the goal of listening task. In applying this strategy, they give full concentration and ignore distraction in listening. Theyhave to focus on information that they know to help them understand and comprehend the text well. This strategy encourage them focus on information that they don't know in listening in order to pinpoint problems and expand their listening comprehension.

The third strategy is deduction/induction. This strategy enables students applying or figuring out rules about language including grammar, phonology, and morphology. This strategy should be apply by the students because by using their knowledge of language rules, it can help their self reliance to monitor their comprehension in listening based on information that they have about the text.

The fourth strategy in monitoring is personalizing or contextualizing. This strategy involves comparing the message from the text tostudent's background knowledge to see if it makes sense. This strategy is important to apply by the students because by checking language input and output against what they know. This strategy helps them ensure that the text makes sense for them. They can connect the information from the text with their experience in order to make it more meaningful and memorable for them.

The fifth strategy is taking notes. This strategy supports the students writing down key words and concepts in abbreviated verbal, graphic, or numerical form while they are listening the text. By applying this strategy, the students can refer back the information they have listened in whilst listening activities in order to complete their listening task. They can write down important information in a format such as $\mathrm{T}$ list, semantic web, or outline that can help the students remember and understand better because they are establishing additional mental links to organize the information. They can monitor their information and divide the information into main idea and supporting detail.

The sixth strategy is using imagery. This strategy can help the student to create their image in order to represent information in listening task. The students can apply this strategy by forming the pictures to check whether the information from listening text makes sense for them. The mental links with images also help the students to remember the information.

The seventh strategy in monitoring is manipulated or act out. This strategy motivates students manipulating tangible object, role playing, or pantomiming the situation to contextualize the information they listened from the text. By using this strategy, the student can create mental 
links with the information and it will help them to learn and remember the information in order to get height comprehension in listening.

The next strategy of monitoring is self talk. To apply this strategy the students make positive statement to their self that they can listen the text well. This is important to do because this strategy reassuring them while doing difficult task in listening.It can help them to think that they can finish the listening task even if they can't do the task perfectly, they can do some of it.

The last strategy of monitoring is cooperative strategy. it encourage the students to cooperate with their friends in order to completing the task in listening comprehension. It also enables them to ask their teacher or lecturer about the text if they have the problem.

In conclusion, monitoring strategy can help the students to monitor the information from listening text by applying nine strategies above in whilst listening activity. These strategies should be applied by the students in listening comprehension with two reasons: first, they monitor how their comprehension while they are listening the text. Second, they monitor the information from listening text by making adjustments to how they are completing the listening task efficiently. If they apply these strategies in the correct ways, they can increase their comprehension.

\section{RESEARCH METHODOLOGY}

The method of the research was qualitative research which applied case study design. It investigated what monitoring strategies used by students, and how they applied it in listening comprehension. The research was conducted at STAIN Batusangkar. The participats of the research were English Students who have taken listening comprehension III. 12 of them have been chosen to be interviewed by using purposive snowball sampling technique.

The instrument of the research were observation, interview and questionaire. Observation and questionaire were used to record and collect real information about monitoring strategies used by students in listening comprehension. After taking the data, the researcher scored the questionnaire by using likert scale. The scores were arranged such as: Always= 5 , Often $=4$, Sometime $=3$, Seldom $=2$ and Never $=1$. She accounted the score of students monitoring strategy, then she analized them. After that categorized and found the percentage of students monitoring strategies.Another data was Interview. It was used to obtain data and to explain what monitoring strategies used by students and how they applied monitoring strategies in listening comprehension. To analyze the data, she used Miles and Hiberman procedure, they are: data reduction, data display, and conclusion drawing/verification. (Miles: 1984).

Then, the researcher collected the data of students listening comprehension achievement. She took it from the lecturer of listening comprehension. After that she categorize the students based on their listening comprehension score. The category were very good, good, sufficient, and poor students.

\section{FINDING}

The data were a set of through questionnaire, interview, and observation dealt with the application of monitoring strategies. The data showed the students' monitoring strategies and the way the students applied these strategies in listening comprehension. Based on the data that had been collected, there were some findings of the research:

1. The students applied monitoring strategies in listening 
comprehension. Based on data analysis, Most of students used monitoring strategies in sufficient category with the percentage $34.07 \%$.

2. The students who were categorized very good, good, sufficient and poor category have applied asking if it made sense strategy in the correct way. The way they applied it such as: asking their comprehension, vocabulary and detail information about the text to them, etc. whereas the good and sufficient students need to develop this strategy in the correct ways because many of them could not explain the way they applied this strategy.

3. The students who were categorized very good and good category applied selective attend strategy better than sufficient and poor category. They applied it by finding the general and detail information from the text. While many students from sufficient and poor strategies did not understand the way they implement this strategy, such as did prediction and focus on unfamiliar vocabularies.

4. The students who were categorized very good and poor category have applied induction and deduction strategy better than good and sufficient category. The way they applied it by using language rule such as grammar to understand the text, but they did not apply phonology and morphology. While there were many students in good and sufficient category who did not give explanation the way the applied this strategy in monitoring their learning.

5. The students who were categorized as very good until poor category had the same way to apply personalize and contextualize strategy. They were connecting what they listened with their experience based on the topic by remembering their experience and knowledge about what they have learned and listened about the topic.

6. The students who were categorized very good until poor students have applied the strategy of take a note almost in the same way. They took a note by numbering the information, took note the general information firstly then wrote the specific information.

7. The students who were categorized very good, good, and sufficient students had implemented this strategy in the correct ways. They used their imagery to make them easy understood and comprehend the text. When they were listening the text, they imagined directly that they were in the situation described in the text. The student from the poor category did not understand well the way they applied this strategy. They did not explain the way they applied it clearly.

8. The students who were categorized very good and good category applied contextualized by contextualizing the language in listening. The way they implemented better than sufficient and poor category. Very good students did not use real object or expression to comprehend the text, while good students applied it by using expression in understanding the text. In spite of this, the sufficient student just used real object to make them understood the information and the poor student just used contextualizing the language from the text and comprehending the expression from the speaker in order to understand the text. 
9. The students who were categorized very good and good category applied self talk strategy by asking their comprehension toward the text. They asked how far they understand the text and the information of the text and checked whether the information right or wrong. The student from this category applied it with the correct way. Beside the student from sufficient and poor category did not understand the way to apply it.

10. Most of the students who were categorized very good until poor category knew the way to apply cooperative strategy in listening. They cooperated with their lecturer and friends in order to get some information from the text. Only student 5 from good category never applied it because she always understand the text, and student 2 from poor category did not know the way to apply it. In short, very good and poor category of students could not apply this strategy well.

\section{DISCUSSION}

The result of the study indicates that most of the students used monitoring in sufficient category in listening comprehension. The way they apply these strategies is consistent with the theories presented by Chamot, Kupper and Goh (1998), Chamot (1999), Papaleontiou (2008) and Oxford (1999).

When the students listened the text in whilst listening activities, they apply this strategy to monitor the information from the text and focus on specific aspect as Chammot (1999) states that "while monitoring the students should think about where their focus of concentration needs to be at any given time and then consciously focus their attention on a specific aspect of the task".
Chamot (1999), Clue in Papaleontiou (2008), Chamot, Kupper and Goh (1998) view that in metacognitive strategies, there is executive monitoring process involved ones' decision that help learners to identify the task on which one is currently working. In monitoring the students do selective attention and directed attention in listening. They applied monitoring strategies such as: ask if it makes sense, selective attend, deduction/induction,

personalize/contextualize, takes note, use imagery, manipulate/act out, self talk, and cooperate strategies". The result of thestudy describe that the students applied theses strategies in listening comprehension with the sufficient category which is affected with the score that they got in listening comprehension test. From the result, the teacher or lecturer should teach this strategy to the students in order to increase their listening comprehension.

Even though most of the students used monitoring strategies in listening comprehension, but for the application, not all of the strategies have been applied well by the students. Not all of them know what monitoring strategies are although they have applied it. It happened since they have lack knowledge about these strategies. They just do the fort folio task is given by their lecturer which is designed these strategies in the task with the instruction for each strategies.

From the previous finding, it can be analyzed that the finding line with the theories from Vandergrift (2004) in which he proposed verification stage which requires monitoring students' prediction and comparing it to others. He also proposed second verification stage in which the students verify points of disagreement and reconstruct general point of the text trough monitoring. 
The finding is also line with Chamot (1999) who introduced the application of monitoring strategies in listening comprehension. He introduces the ways to apply monitoring with the strategy of selectively attend by focusing on the topic in whilst listening activities. To apply deduction or induction strategy. The students can apply it by understanding grammar and phonology in the listening text. For personalize strategy, he suggests the students to apply it by remembering their personal experience and relate it with the topic they are listening. He also introduces take a note strategy. He proposes the students to apply it by writing the general and specific information from the text. Furthermore use imagery strategy. The students can apply it by imagining the situation based on what they listened in the text. $\mathrm{He}$ also introduces to apply manipulate strategy by using real object, expression and contextualization to comprehend the text. Furthermore he proposed self talk strategy in which the students can ask themselves to monitor the information they listed from text. Finally he suggest the students to apply cooperative strategies by discussing with friends or lecture about the listening text. Compare with the finding of monitoring strategies and what the expert said, it can be inferred that some of the students have applied monitoring strategies into the correct ways.

In contrast, the good and sufficient students did not ask if it made sense strategy in the correct ways because many of them could not explain the way they applied this strategy. For selective attended strategy, many students from sufficient and poor strategies did not understand the way they implement this strategy, such as did prediction and focus on unfamiliar vocabularies. Then many students in good and sufficient category did not give explanation the way the applied deduction and induction strategy in monitoring their learning. Finally the student from sufficient and poor category did not understand the way to apply self talk strategy. The findings were not line with the theories proposed by Chamot (1999).

In conclusion, not all of the students applied monitoring strategies with the correct ways. They have to pay attention to apply the strategies of asking if it made sense, selective attend deduction, and self talk. They need to develop them effectively and get more understanding about the way they applied these strategies not only in the classroom but also outside of the classroom.

\section{CONCLUSION}

There are nine strategies applied by students on monitoring related to the way they applied this strategy: (1)The student from very good until poor category have applied asking if it made sense strategy in the correct way, (2)The students from very good and good category applied selective attend strategy better than sufficient and poor category,(3) The student from very good and poor category have applied deduction and deduction strategy better than good and sufficient category, (4)The students who categorized as very good until poor category had the same way to apply personalize and contextualize strategy, (5)The students who categorized as very good until poor students have applied the strategy of take a note almost in the same way. (6)The students from very good, good, and sufficient student had implemented imagery strategy in the correct ways. 
(7)The students from very good and good category applied contextualized by contextualizing the language in listening, (8) the students from very good and good category applied self talk strategy better than sufficient and poor strategy, (9) Most of the students from very good until poor category knew the way to apply cooperative strategy in listening.

\section{REFERENCES}

Chamot, A. U.1999, The Learning Strategies Handbook, New York: Longman.

Goh.C and Taib Y. "Metaconitive Instruction in Listening for Young Learners". Retrieved on July 3, (2006), ELT Journal Volume 3, p. 222-223.

Goh, C. C. M. 1998. How ESL learners with different listening abilities use comprehension and tactics. Language Teaching Research, 2(2), 124-147.

Oxford, R, L. 1990. Language Learning Strategies. New York: Newbury House Publishers.

O'Malley, J. M., Chamot, A. U., \& Kuper, L. (1989). "Listening comprehension strategies in
The way the students apply monitoring strategies need to improve in order to increase their comprehension in listening. The teachers or lecturers should encourage the students in applying these strategies into the correct ways by designing monitoring strategy instruction and teach them to use these strategies in completing the task.

second language acquisition". Applied Linguistics, 10(4), 418437.

Miles, B. Matthew. (1984).Qualitative Data Analysis: A Sourcebook of New Methods, Beverly Hills: Sage Publication.

Papaleontiou,

Eleonora. (2008).Metacofnitive and Theory of Mind. New Castle: Cambridge Scholars Publishing.

Vandergrift, L. 2004. "Facilitating second language listening comprehension: acquiring successful strategies ".ELT Journal, 53(3), 168-176.

Wenden, Anita \& Joan Rubin. 1987. Learners strategies in Language Learning. London: Prantice Hall 